\title{
THE STRATEGIC IMPLICATIONS OF THE US AND CHINA'S ENGAGEMENT WITHIN
} AFRICA

\author{
Jan van Rooyen and Prof Hussein Solomon \\ Department of Political Sciences, University of Pretoria
}

\section{Introduction}

The role of external involvement within Africa is not a new phenomenon by any standard; in fact, Africa's recent political history is rife with similar examples. From the onset of colonisation, European powers have been subjugating and manipulating Africa's people for their vast supplies of natural resources and raw materials. The Africa of today is no different, with a noticeably growing trend of external involvement within the continent. The changing geostrategic realities of the post-9/11 world have entrenched Africa as a new strategic destination due to the prevalence of crucial resources and possible markets and the security interests of global powers. The shift in focus towards Africa as a strategic partner in the changing geo-political realities of the contemporary international system has posited the emergence of the so-called 'new scramble for Africa'. In essence, this scramble revolves around the widespread interest in Africa's resource-rich countries as a vital source of security for the world's economic powers. Recent engagement within Africa is rooted in the quest of foreign countries to secure access to finite resources and raw materials as well as to open export markets.

The world's economic powers are repeatedly engaging in dialogue with African countries. The legacies of colonialism and the resultant connections with European governments have fostered the continual presence of France and Great Britain on the continent, as well as constructive dialogue with the European Union and individual European countries. African oil-producing countries have also attracted the attention of the Oil and Petroleum Exporting Countries (OPEC) as well as a marked interest by the People's Republic of China (hereafter 'China') and the United States of America (US). Africa is in the process of being repositioned as a crucial partner within the global economy and a wide variety of actors and 
states/countries are attempting to establish and foster direct links with African countries.

Although many actors are increasingly turning towards the African continent, China and the US are playing an increasingly visible role in this scramble for Africa. Although these two countries do not share all of the same intentions on the continent, they are both engaging in Africa for the salient purpose of securing access to Africa's bountiful resources. The resource endowments within African countries, particularly those pertaining to Africa's oil supplies, have proved to be of vital interest to the US and China. The result has been a marked engagement by both the US and China to secure access to these oil resources. The importance of Africa's oil resources in the current global economy is highlighted by the fact that the demand for energy is estimated to rise by more than 50 percent by the year 2030, of which 80 percent would still be met by fossil fuels (Statement on Global Energy Security Principles, 2006). Given the political volatility of traditional supplying regions like the Middle East, many countries are turning to Africa's largely untapped energy resources.

This article looks at the reasons for the resurgence of interest in Africa by China and the US. The primary contention is that securing oil resources is of paramount importance, although other reasons will also be explored. Further, the implications of engagement by the US and China in Africa will be examined, with a particular focus on the ongoing conflict in the Niger Delta as a case study.

\section{Changing geostrategic realities and the new scramble for Africa}

The contemporary market-driven international economy functions within the fundamental capitalist premise of the continued infinite accumulation of wealth, with little regard for the finite nature of the global system. Ultimately, the global economy operates according to a flawed premise surrounding the infinite and continued availability of natural resources and raw materials. The fact of the matter is that the earth is a finite system with limited amounts of natural and raw materials that can be exploited and used towards capital accumulation. Consequently, the finite nature of the earth's resources is a potential catalyst for conflict and competition both between and within countries. As a direct result, the scarcity of the earth's resources has created an environment in which resource acquisition and subsequent security have taken centre stage within many countries. The continued availability of affordable and uninterrupted supplies of crucial strategic resources has manifested into the securitisation of resources and resource supplies. Major oil consumers, such as the US and China, have securitised oil as a fundamental resource 
necessary for the continued prosperity and functioning of their respective countries (Thayer, 2005:72). The securitisation of oil lends itself to many problems and concerns, such as the willingness and extent to which countries are prepared to mobilise military forces tacitly or overtly to protect vital strategic resource interests.

The securitisation of resource interests led to the development of the concept resource wars which is associated with rapid economic growth leading to a rising demand for and acquisition of raw materials, coupled with expected resource shortages and contested resource ownership (Le Billon, 2004:4). The reality of the contemporary global system is that resource competition is imminent, arising either within countries as has been the trend in resource-rich countries, or between countries as the projected future trend. The securitisation of strategic resources as well as the looming scarcity of such resources - especially oil - across the globe, foreshadows a changing geostrategic landscape driven by access to and acquisition of resources supplies.

At present, the world's oil supply and production capabilities are reaching their peak. Today, global oil production is barely one million barrels a day over global consumption, implying that the rising surge in demand from developing countries, especially China, will lead to global demand outstripping supply in the next two decades (Pocha, 2005:52). Given the ever increasing demand for oil which is set to outstrip supply by 2020 and the fast approaching peak of oil production expected by 2010, the subsequent political and economic consequences will most probably manifest in an increase in conflict associated with energy and resource security (Peters, 2004:197). The potential for conflict is especially rife in the developing world as 80 percent of the world's oil reserves can be found in the socalled 'global south', residing within impoverished countries with weak political and economic structures. (Peters, 2004:212).

The presence of large supplies of resources in African countries serves as a catalyst for conflict and political upheaval. The fundamental importance attributed to resources by the developed industrialised nations of the 'global north' will fuel and perpetuate conflict and political turmoil within Africa's resource-rich nations. The strategic importance of oil and minerals to the United States of America and China in particular, has greatly altered their relationship with Africa and African countries and will continue to do so. Furthermore, the presence of strategic resources in African countries manifests in artificial power to the political centre and a subsequent lack of access to benefits accruing from resource wealth by Africa's long-suffering citizens (Osaghae, 2004:225). The resultant effect is an increase in conflict over access to and control over strategic resources. Detrimentally, the 
presence of external actors serves to fuel and exacerbate conflict by supplying financing, military assistance and political legitimacy to otherwise neo-patrimonial governments. Conflict over resources will therefore greatly influence and affect the political and economic vulnerabilities of resource-rich African countries (Le Billon, 2004:1).

The emerging trend of external involvement in Africa by both China and the United States for control over resources has a large impact on the political climate on the African continent and will continue to do so. Such external involvement by strong powers could have many political consequences for weak, impoverished African countries. While competition for strategic resources in Africa is the fundamental characteristic surrounding the stylised 'new scramble for Africa', the political, economic and social benefits derived from this quest to secure African resources must, in turn, be weighed against the potential to fuel and exacerbate conflict on the continent (Kraxberger, 2005:50).

\section{China as an emerging power}

China has experienced rapid and unprecedented economic growth lately at the hand of an aggressive export-driven economic policy orientation. The geostrategic implications of China's rapid economic growth are becoming more and more evident as crucial resources become increasingly scarce. What China needs most at this stage are resources to fuel the country's rapid industrialisation and economic growth. Bearing this in mind, China's quest for oil and energy security raises a number of implications for its role as a growing power in Asia and the rest of the world and especially as regards its engagement in Africa.

\section{The Chinese economy - the case of rapid growth}

The emergence of China as a global player is a consequence of the country's rapid economic growth and development, following a marked shift in internal policy. The China of today is actively pursing international engagement and strong economic development - a radical alteration from the isolationist stance under Mao Zedong (Muekalia, 2004:10). Following a shift in focus to export lead growth, China has witnessed unprecedented levels of economic growth and development. From 1981 to 1991, the country's exports have grown by an average of 13 percent per year, with exports after 1991, growing by a further 18 percent per year (Hale, 2006:6). In direct correlation, China's total share of world exports has risen from 1.1 percent in 1981 to just under 7 percent in 2005, making China the third largest exporting nation following closely behind the US and Germany 
(Hale, ,2006:6). Barring any unforeseen drastic economic changes, China’s rapid export lead growth will result in that country becoming the world's largest exporting nation by 2010 and surpassing Germany as the world's second largest economy by 2020 (Jenkins \& Edwards, 2004:3).

Driven by exports, China's economic growth is unprecedented in the world today, with the gross domestic product (GDP) expected to rise by 8 percent annually (Rethinaraj, 2003:377). GDP growth within China has been rapid and sustained over the past couple of decades with an average GDP growth of 9.7 percent up to 2000. In 2001, GDP growth was a stark 7.5 percent, in 2002, 8 percent and in 2003, 9.1 percent (Mills \& Skidmore, 2004:1). Subsequently, if Chinese growth rates are maintained by 2010, China will have a larger manufacturing sector than the US and will far surpass the US as the world's leading consumer of most raw industrial materials (Hale, 2006:9). Not surprisingly thus, the combined economies of China, Taiwan and Hong Kong stand at \$1 437 billion, making 'Greater China' (including mainland China, Taiwan and Hong Kong) the fourth largest economy in the world (Mills \& Skidmore, 2004:1).

\section{Energy security and the quest for oil}

China's foreign policy, diplomatic relationships and strategic outlook are increasingly driven by the quest for energy security. Conceptually, energy security equates the "availability of energy at all times in various forms and in sufficient quantities and at affordable prices” (Umbach, 2003:141). China's engagement and policy focus on securing its supplies of energy did not emerge until 1993 when the country became a net oil importer (Lee, 2005:267). Consequently, the search for oil has taken the Chinese all over the world in pursuit of a bilateral approach to energy security with oil producers (Jaffe \& Lewis, 2002:115). The net result has been a marked increase in the aggressive search for oil concessions at all costs by the Chinese government and its energy parastatals.

The rise in China's economic growth has spurred a growing demand for oil and energy security. In 1993, China's domestic oil production was no longer sufficient to meet the rapid increases in demand. For the first time, therefore, China had to import 6.4 percent of its total oil consumption. As expected, China's dependence on imported oil has grown substantially since 1993, and in 2002 the country needed to import 31 percent of its total oil consumption with the figure projected to skyrocket to 60 percent by 2020 (Giry, 2004:22). In 2005, China overtook Japan as the second largest oil importer, only trailing behind the US, with a 50 percent increase in total oil demand from 1993 to 2003 (Lee, 2005:268). If 
China's current demand remains consistently at an increase of 7 percent per year, it will reach the current level of oil consumption of the United States by the year 2025 (Thayer, 2005:75).

China's growing demand for oil has resulted in a national policy of securing one third of its energy needs through aggressive exploration and acquisition of foreign oil concessions (Jaffe \& Lewis, 2002:123). As a result, the Chinese have been actively pursuing opportunities to buy into oil production and horizontal aspects of the oil trade. Given the increased instability of the Middle East and the growing security risks, China is searching for alternative sources of oil to decrease its dependence on Middle Eastern oil. Therefore China has been pursuing links with Russia, albeit largely unsuccessfully, as well as with African and South American oil producers (Lee, 2005:280).

China's acquisition methods have essentially been called into question, and have raised a number of fundamental problems within the larger consideration of international oil security. Furthermore, China's aggressive policy towards energy security and securing oil is the consequence of established international and multilateral norms of conduct. China has thus followed a singularly bilateral oil strategy, preferring to negotiate and work directly with oil producers and host governments as opposed to buying from and working within multilateral frameworks established to ensure global oil security (Jaffe \& Lewis, 2002:115). The result has been that Chinese oil acquisition strategies have focused on exploration within countries that are seen as being either 'rogue countries' of too high political risk, or countries barred by sanctions. Ultimately, this means that Chinese companies are able and willing to go to countries where Western oil firms cannot (Jaffe \& Lewis, 2002:128). The result is that Chinese activities in oil-producing countries are neither subject to transparency and legitimacy, nor to international normative values of good governance and domestic accountability. The implications are dire, as the Chinese have been known to supply arms, military equipment and technology in return for oil concessions (Jaffe \& Lewis, 2002:125). Although supplying arms and artificial support to dissident governments for oil concessions is not a new phenomenon, the problem arises in the overt and tacit support that the Chinese government gives to such policies. Beijing firmly upholds the tradition of state sovereignty above normative values, providing an avenue for neo-patrimonial governments to bypass the West in search of foreign direct investment (FDI) and political support. 


\section{China's engagement with Africa}

China's engagement with Africa is based on four fundamental pillars, namely soft power (the extension of diplomatic support), direct competition with Taiwan, the strengthening of economic and trade links, and the increasing salience of energy security (Alden, 2005:153). Consequently, China's relationship with Africa has been one marred by shifting priorities within the foreign policy outcomes of Beijing. The first signs of China's renewed interest in the African continent were directly related to the events surrounding Tiananmen Square in 1989 when government troops massacred unarmed civilians who were protesting communist rule. Following this, the West's perception towards Chinese human rights abuses, previously ignored, gained greater salience and importance. As a result, the West became increasingly critical towards the Chinese for what was perceived as gross human rights violations by the central government. In response to the backlash arising from the West against China, China began to revisit the importance of its role within developing countries as a whole and Africa in particular (Taylor, 1998:443). Africa began to be viewed as a source of political allegiance against the West both within bilateral arrangements and multilateral platforms. Since 1997, China has sent more than 30 high-level delegations to Africa, in an active attempt to strengthen its political, economic and military relationships with individual African countries (Muekalia, 2004:8).

\section{Taiwan and Beijing's one Chinese policy}

The continuing conflict between mainland China and Taiwan over diplomatic recognition has spilled over to the African continent as Taiwan is actively pursuing diplomatic recognition from impoverished African countries. Both China and Taiwan are seeking to exclude each other from gaining ground within the African continent as Taiwan struggles for international recognition and China purports its 'One China' doctrine. Ultimately, what has emerged is the growing use of 'dollar diplomacy' by Taiwan in securing diplomatic recognition (Taylor, 1997:192). Subsequently, Taiwan targets impoverished African countries in need of financial assistance in the form of loans and development aid in return for diplomatic recognition. In response, China leverages its economic and political weight to dissuade ties with Taiwan and to reaffirm the formal recognition of mainland China as sovereign over Taiwan (Mills \& Skidmore, 2004:2). The result has been largely beneficial for impoverished African countries as they are willing to swap recognition of one over the other in return for hard currency (McLaughlin, 1997; Tefft, 1996:7). Although the potential use of coercive and potentially covert 
punishment or retaliation by China against African countries that support Taiwan exists, there have been no documented cases of such measures being applied yet. However, the potential to support corrupt and abusive governments exists, as both Taiwan and China disregard political, social and economic criteria when seeking recognition.

\section{China's soft power}

In line with China's continued conflict with Taiwan, one of the fundamental tenets surrounding engagement with Africa is that of spreading China's soft power. China perceives African countries as a source of political clout in multilateral forums such as the World Trade Organisation and the United Nations. As a member of the Security Council, China has one foot in the door with the developed industrialised nations of the world, whilst maintaining and strengthening close ties with the developing world (Muekalia, 2004:10). As such, China is actively portraying itself as having a crucial leadership role within the developing world (Jaffe \& Lewis, 2002:128). Subsequently, in order to secure and consolidate support from African leaders, China is pursuing a number of soft power methods, and the country is actively involved in public works programmes, agricultural development, and building telecommunications infrastructure (Giry, 2004:22). China is also directly involved in building roads in Kenya and Rwanda, whilst assisting in construction projects in Ethiopia, Tanzania and Zambia (McLaughlin, 2005:5). China has also promised debt relief of $\$ 1.27$ billion dollars to 31 African countries (Alden, 2005:152). China has further been involved in what has been termed 'symbolic diplomatic and development assistance' in an attempt to consolidate the relationships between African countries and China. These ongoing initiatives have taken the form of, for example, the construction of a new Foreign Ministry building in Uganda, stadiums in Malawi, and a new House of Parliament in Mozambique complete with a mural of the Great Wall of China in the foyer (Alden, 2005:151). These initiatives are designed to increase China's perception of Africa as a means to consolidate its support base and power within the realm of international politics. This is not to discount the role of soft power within securing economic gains and energy security from Africa, but ultimately everything has its price, and China's revolves around market access and strategic mineral- and resource-driven relationships.

\section{Economic and trade links}

A further tenet driving China's engagement with Africa revolves around increased economic and trade links whilst opening up market access for Chinese 
companies in Africa. The rapid increase in Chinese economic development has been largely propelled at the hands of aggressive export lead growth. As a result, Chinese exports account for 38 percent of China’s GDP, whilst foreign firms produce close to 60 percent of all Chinese export earnings (Mills \& Skidmore, 2004:10). Against this background Chinese companies are actively engaging in Africa for export markets as well as for sources of labour and raw materials. Furthermore, China views economic links with Africa as crucial to its market expansion, especially with regard to commodities and natural resources (Mills \& Skidmore, 2004:2). In the past decade, over 600 Chinese companies have been established in Africa with a total investment since 1990 of \$625 million dollars, and in 2004 alone of over \$139 million dollars (Alden, 2005:150).

China's economic links with Africa have been directly strengthened through the multilateral signing of the Beijing Declaration at the China-Africa Cooperation Forum in Beijing in 2000. The Beijing Declaration outlines a firm commitment between African countries and China for increased cooperation in economic and international affairs with the view to creating a "new political and economic order” between China and Africa (Muekalia, 2004:4). Subsequently, following the China-Africa Cooperation Forum, two-way trade between China and the African continent rose by 20 percent between 2000 and 2003. Meanwhile, China's export trade with Africa rose by 50 percent to $\$ 18.5$ billion over the same period (McLaughlin, 2005:4). Furthermore, 117 new Chinese companies have been established in Africa and 7000 African personnel have been trained by Chinese advisors (Muekalia, 2004:6). As a result of the strengthened economic relationship between China and Africa, China hopes to double its trade with Africa to \$30 billion dollars by 2008 (Mills \& Skidmore, 2004:2). Consequently, China is projected to be one of the top three investors on the continent within five years, particularly in the oil and mining sectors of African economies (Jenkins \& Edwards, 2004:26).

\section{Energy security}

Indirect conflict with Taiwan in Africa, increasing soft power, as well as economic relationships, are at the behest of China's future energy security. The fact remains that China's primary focus in Africa is to secure concessions of strategic resources and minerals for the future benefit of the Chinese economy. In view of China's rapidly rising dependence on oil and the increased insecurity within the Middle East, China is actively pursuing and obtaining new avenues of strategic resources on the African continent. This is due to a number of latent reasons. Firstly, African oil is generally of a higher quality than oil from most other sources. This enables China to use its present domestic refining capabilities, as African oil is very 
similar to China's domestic oil product (Giry, 2004:23). Secondly, African oilproducing countries tend to be highly indebted and impoverished, thus raising the possibility for oil concessions in return for military, economic and financial assistance. Thirdly, African oil reserves are largely untapped with less competition than elsewhere, affording many opportunities for China's state-run oil companies to invest horizontally in African countries' mining and refining capabilities. To exemplify this point, proven oil reserves in West Africa have doubled to 60 billion barrels of crude oil. Subsequently, by 2010 West Africa will produce one fifth of the world's oil output (Giry, 2004:22). It is therefore not surprising that the trend in China's oil expropriation has seen a large increase in dependence and involvement with African oil.

China's dependence on African oil is such that 25 percent of imported oil comes from Africa, which makes it the second largest source of Chinese oil (Giry, 2004:22; Rethinaraj, 2003:384). In 2002 China imported \$3 billion worth of oil from Angola and Nigeria (Muekalia, 2004:4). As a result of the increased dependence on and strategic shift to African oil, Chinese firms are encouraged to buy directly into state oil capabilities, allowing China to have a direct link to oil production and to bypass conventional methods of buying oil on the international market. The China National Petroleum Corporation (CNPC) owns 40 percent of Sudan's oil venture. It also invests heavily in Angola, Algeria, Gabon and Nigeria, and is exploring and fostering links with Equatorial Guinea and the Democratic Republic of Congo (Hale, 2006:18).

\section{The political consequences}

Chinese involvement in Africa is not without its consequences to African countries and in particular the African people. The increased involvement of China in Africa raises a number of questions surrounding China's non-critical and rigid interpretation of the principle of state sovereignty. In essence, Chinese engagement in Africa is devoid of any conditionalities and restrictions surrounding accountability, good governance, political legitimacy and adherence to human rights norms. This has served Chinese interests in that China is willing to deal with countries that violate international norms of good conduct and governance. Ultimately, China's unwillingness to impose restrictions and conditionalities to aid, financial assistance, and economic and military cooperation has undermined the efforts by the United States and the international community to reform African countries (McLaughlin, 2005:12). This in turn has created a lack of political will towards reform within corrupt, nepotistic and despotic African governments as China forges an alternative towards engagement with the West and their subsequent 
conditionalities (Giry, 2004:22). As a result, corrupt governments and parasitic leaders are able to remain in power, receiving much needed aid and economic development from China in return for market access and resources.

In return for aid and assistance regarding economic development without the attachment of conditionalities and political criticism, the Chinese ask for market access for their companies and products. This, however, has opened a Pandora's Box for impoverished African countries, as the Chinese are increasingly using Africa as a market on which to dump manufactured products. As impoverished African countries are less likely to approach the World Trade Organisation's dispute settlement mechanisms, Chinese companies are repeatedly flooding African markets with their inexpensive products, undercutting local prices and hurting domestic production (Alden, 2005:149). Furthermore, Chinese firms are encouraged to establish themselves in African markets, ultimately competing against under-skilled, impoverished African traders. The result is such that Angola's Energy Minister has been reported to say that due to the rapidly expanding economic links with China three million Chinese could move to Angola over the next five years (Hale, 2006:18).

To exacerbate the political consequences of China's involvement in Africa further, the Chinese are actively providing military assistance and arms in return for oil concessions. For example, Human Rights Watch has implicated Chinese oil companies in supplying arms to Eritrea and Ethiopia, Sudan and Nigeria, to name but a few. Furthermore, it is has been claimed that Chinese companies were complicit in helping the Sudanese government displace populations in Southern Sudan to make way for oil projects (Giry, 2004:23). During the ongoing conflict in Sudan, Chinese oil purchases have enabled the Sudanese government to buy arms to continue the violence and intimidation campaigns in Darfur (Giry, 2004:23). The implications are dire, as Sudan holds crucial deposits of oil, yet is a fragile society emerging from decades of civil war and the recent allegation of genocide in the Western Darfur region. Conversely, the United States has imposed sanctions on the government in Khartoum in an effort to bring an end to the violence; however, with China's presence the sanctions do little more than placate Western minds.

The greatest lasting impact of the Chinese in Africa is their complete disregard for governance and human rights when dealing with African countries. The involvement of China will thus further exacerbate poor governance, corruption, and human rights abuses across the continent, doing little for the concerted campaigns towards democratic and accountable governance. Although Chinese involvement in Africa is of great benefit to African leaders and neo-patrimonial 
African countries, the implications for African people are dire (Kraxberger, 2005:55). Ultimately, China's engagement in Africa will continue to exacerbate the polarised divide between those who have access to government resources and those marginalised by the central state. The potential to fuel conflict is real as China's involvement does nothing to address the latent causes of conflict on the African continent; it rather serves to heighten and strengthen the sources of state-controlled violence and political repression (Zalik, 2004:405).

\section{The United States and Africa}

The United States and Africa have had a strenuous relationship marred by uncertainties and dogmatic policy shifts. During the 1990s, American policy-makers and media largely ignored Africa. What little attention Africa received revolved around war, conflict and famine. Although the attention paid to Africa by the Western media today is largely the same, the US is undergoing concerted policy shifts towards engagement with the African continent (Alden, 2000:356). The shift in orientation from marginalisation to engagement is largely due to the changing geostrategic realities of the post-9/11 world. Today the US government is primarily concerned with curbing international terrorism and ensuring energy security for the US economy in the years to come. As a result, the focus in Africa has been shifted towards the role played by weak and failed countries that foster terrorism and terrorist networks. The US government is engaged in promoting good governance and democratic accountability as a way to curb the latent forces that breed terrorism in Africa. The second pillar of American policy engagement in Africa rests in securing strategic minerals and resources for American consumption (Alden, 2000:356). The reliance on Middle Eastern oil is tenuous at best and wrought with many uncertainties and subsequent security risks. Thus, there is a move in US policy towards engagement with African oil-producing nations as a means to secure alternative sources of crude oil for the US economy. The United States' engagement in Africa is thus pragmatic and fuelled ultimately by larger geostrategic concerns.

\section{Democratisation, human rights and good governance}

The United States has continually been concerned with the tenets of democratisation, human rights and good governance as solid foundations of the nation state. It is through this combination of governance and accountability followed by free market policies and integration in the world economy that the US purports to deliver economic growth and political stability. Subsequently US policies towards Africa have shifted from the dogma of structural adjustment during the 1980s and early 1990s towards governance and political accountability (Alden, 
2000:358). This shift was markedly intensified by the events of September $11^{\text {th }}$ 2001, as a result of which the US has begun to focus on the tenets of failed countries and weak governance and a subsequent lack of security within African countries as a potential source of terrorism. As a consequence, the US has stressed the importance of political legitimacy and strong internal cohesion as a means to stem the potential growth of terrorist networks within weak African countries. In fact, the United States views Africa as a potential security risk, emanating from the failure of countries to control their borders and their internal populations adequately (Bromley, 2005:227). The US has, however, a supercilious role in promoting and encouraging standards of governance and political accountability within African countries. Often siding with corrupt and illegitimate governments in return for access to strategic resources, namely oil, the US runs a fine gambit between dogma and pragmatism when it comes to strategic issues of importance to national security.

\section{The war on terror}

The United States has identified weak African countries with large Muslim populations, especially in Eastern Africa and the broader Sahel region, as being potential sources of international terrorism in the near future. Following September $11^{\text {th }}$ 2001, the immediate response of the US was to look for means to intervene militarily on the continent in order to pre-empt the growth of terrorist networks within African countries. However, the shift has moved towards enhancing the military and security capabilities of individual African countries as well as regional security initiatives (Biel, 2003:86). As a result, the US has donated over $\$ 100$ million to East African countries to train their security and military forces so as to control porous borders more effectively, block means of financing available to terrorists and enforce tougher and more stringent aviation security (Giry, 2004:23). In Kenya, the US has strategic links with security forces and police in an effort to strengthen Kenyan anti-terrorism capabilities and to enhance the possibility of amphibious landings by US soldiers off the Kenyan coast (Biel, 2003:86). Subsequently, changing US strategic interests have yielded the necessity for a greater military presence both tacitly and overtly on the African continent. Not only does the US spend money on strengthening the military and security services of individual countries, they are also actively involved in enhancing their force presence on the African continent through the planned establishment of full military bases as well as what are termed 'lily pads' or jumping points. These points are used to refuel aircraft, temporarily accommodate personnel and actively carry out surveillance and covert counter-measures (Barnes, 2005:239). This is largely due to the growing threat of terrorism, but also to the evolving strategic value of Africa in securing American national interests. 
The threat of international terrorism stemming from and strengthened within African countries is both real and credible. There is speculation and growing concern about weak and failing African countries that are unable to counteract the formation of terrorist training camps within their borders (Kraxberger, 2005:58). Furthermore, there is convincing evidence that terrorist networks are operating within South Africa, Kenya, Niger, Chad, Algeria and probably also in Somalia (Barnes 2005:239). Weak African countries and their subsequent porous borders are affording many opportunities for the free movement, training and facilitation of international terrorist networks. Northern Africa's proximity to both Europe and the Middle East is cause for concern as regards the spread and movement of international terrorist cells and organisations (Keenan, 2004:476).

\section{Energy security}

The US economy is increasingly dependent on foreign sources of oil as rising demand and declining domestic supplies are causing a growing reliance on oil imports to meet domestic requirements (Giry, 2004:23). At present, the US imports roughly 50 percent of its oil and this is expected to rise to 62 percent by 2020 (Volman, 2003:574). This has placed American policy-makers in a precarious situation of securitising the access to oil as fundamental to American national interests. In fact, even as far back as the 1973 oil crisis, energy security has been of primary importance to US foreign policy (Peters, 2004:196). Given the emerging instability in the Middle East, the US is actively ensuring the security of its energy supplies through diversified sources of oil and natural resources (Umbach, 2003:141).

As the United States became more and more reliant on imported oil to meet its domestic demands, the country turned to African countries and producers as alternative suppliers. At present, the US consumes one quarter of the world's oil output of which 13 to 18 percent is being met by Central and Western African oil producers. Consequently, the United States' Central Intelligence Agency (CIA) predicts that within the next 10 years the US will depend on African oil for 25 percent of its total consumption. This will largely emanate from Nigeria, Angola, Gabon and Equatorial Guinea (Barnes, 2005:237). The shift in policy towards exploiting African sources of oil has led President Bush to declare that West African oil is the 'fastest growing source of oil and gas for American markets' (Giry, 2004:23). With an estimated $\$ 17.8$ billion dollars being spent on developing African oil in 2004 and an investment by US companies of between $\$ 30$ billion and $\$ 40$ billion in West and Central African oil fields over the past decade, it is not 
surprising that the US is seeking a more active role on the African continent (Barnes, 2005:237).

\section{The political consequences}

Precisely what role the United States is playing on the African continent has created much scepticism and doubt. The dogmatic pursuit of democratisation and good governance on the African continent is marred by a willingness to engage with corrupt and neo-patrimonial African countries in search of energy security. For instance, US companies are involved in Equatorial Guinea, Nigeria, and the DR Congo, none of which are bastions of good governance and respect for human rights on the African continent. However, all three countries host crucial oil deposits. Furthermore, with oil prices increasingly rising and Middle Eastern security at an all-time tenuous position, the US war on terror is a viable cover for increased involvement with African countries (Bush, 2004:384). If Angolan or Nigerian oil supplies were to be interrupted there would be very few replacements outside of the Middle East that could match their productive capabilities and exports to the US (Barnes, 2005:237). Therefore, since the 1973 oil crisis securing US energy supplies has been a top priority in US foreign policy. This is followed by post-Cold War 'resource wars' being justified by the fight against terrorism and the proliferation against weapons of mass destruction (Peters, 2004:196).

The potential political outcome of the shifting strategic importance of Africa within the broader framework of US national security has dire consequences for the viable prospects of a peaceful continent. The securitisation of US energy resources has placed securing access to cheap and reliable resources as a prime foreign policy objective of the United States (Verrastro et al., 2004:10). Consequently, this takes precedence over the tenets of democratisation and good governance on the continent. As an example, the role of the United States in Nigeria has furthered the conflict emanating from the Niger Delta. The political implications of continued US involvement in Africa surround the increased military presence on the continent as well as the securitisation of oil resources. Tacitly, the US sees its access to strategic minerals as the most important aspect of its engagement in Africa. This calls into doubt the viability of democracy, governance and ultimately peace on the continent.

\section{Case study: Nigeria, oil and external involvement}

Nigeria has emerged as a vital partner in US energy security policies due to the growing instability of world oil supplies (Ikelegbe, 2005:209). It is estimated 
that Nigeria's oil reserves stand at roughly 22.5 billion barrels of crude oil. With an average production of 2.1 million barrels per day and a subsequent average export of 900000 million barrels per day to the United States, Nigeria is the fifth largest oil exporter to the US, directly following Venezuela, Canada, Mexico and Saudi Arabia (Volman, 2003:575). It is expected that by 2010 Nigeria will more than double its exports to the US to around 2.1 million barrels per day with a further increase to 3.3 million barrels per day by 2020 (Volman, 2003:576). American interests in Nigeria are guided by America's long-term strategic interests of securing oil resources in Africa. To ensure the continued prosperity of Nigerian oil, the US has pledged millions of dollars in military and technical assistance to maintain a strong Nigerian state. In 2003, the US Department of Defence made provisional plans to sell $\$ 4.5$ million dollars' worth of military equipment to Nigeria and has guaranteed another $\$ 12.6$ million dollars' worth of equipment coming from US private arms manufacturers contracted by the state. This is followed by a commitment for military training of Nigerian army officers in combat operations and administrative functions (Volman, 2003:577). The intended purpose of providing military equipment and training is directly linked to the strategic rationale of US national interests, ultimately ensuring that the Nigerian state is able to protect US companies, Exxon Mobile and Chevron Texaco, and their related oil operations in the volatile Niger Delta.

Nigeria's experience as an oil-exporting nation has not been without controversy, violent conflict and political turmoil. The derivative effects of the resource economy in Nigeria have fuelled the latent characteristics of resource-based conflict within the state. Fundamentally, the conflict arises from the marginalisation and successive exclusion of the people in the Niger Delta from reaping the economic benefits of their oil-rich region (Omeje, 2004:438). Following independence, successive Nigerian governments have lessened the portion of oil money allocated to the peoples of the Niger Delta. In 1967, the Niger Delta region was allocated 50 percent of all oil revenues. That has declined to three percent. Furthermore, the region has been continually marginalised and subjugated, with little or no economic, social and political development. In short, the Niger Delta has greatly contributed to enriching the Nigerian state, whilst successfully becoming the poorest and least developed region of Nigeria (Ikelegbe, 2005:214). Consequently, there has been an increase in popular and violent resistance to multinational and government agencies operating within the Niger Delta. Since the 1990s, the resistance has become widespread and far-reaching throughout the Niger Delta with concerted efforts to halt production by abducting and holding multinational staff ransom, and hijacking helicopters, boats and shipping vehicles. There is also violent armed resistance by youth militias and militant groups (Ikelegbe, 2005:215). Today the conflict 
continues unabated with little or no reprieve for the impoverished peoples of the Niger Delta region.

The ultimate intention of the people within the Niger Delta has simply been to access the large financial benefits from oil production, which they perceive to have been stolen from them by corrupt politicians and foreign oil corporations. The reaction from multinational oil companies and the Nigerian state has been what Michael Watts has termed 'petro violence' (Zalik, 2004:402). As such, 'petro violence' refers to the joint initiatives by Nigerian military forces and oil companies to secure oil production and the environment against social unrest within the Niger Delta (Zalik, 2004:402). Foreign oil companies and the Nigerian state are thus driven by the need to secure and maintain oil production within the Niger Delta at the ultimate cost to the impoverished people in the region. The result has been an exacerbation of the conflict between militant groups and the Nigerian government. In 2005, it was estimated that conflict in the region reduced Nigeria's total oil production by 40 percent (Ikelegbe, 2005:223). Since Nigeria derives 70 to 80 percent of its revenues from oil production, a loss of 40 percent is a substantial blow to its financial capabilities (Zalik, 2004:405). Increasingly worrying, however, are the allegations surrounding the deployment of US marines to conduct security surveillance and to protect oil installations and shipments (Ikelegbe, 2005:223). The involvement of the US military in securing strategic oil resources in Nigeria is not a far-fetched allegation and in fact, US military engagement on the African continent is steadily rising as the US views Africa as of increasing strategic importance.

The effects of oil exploitation on the Niger Delta and the greater tenets of political stability within the Nigerian state serve as a prime example of the role of oil in internal resource conflict. Furthermore, the Nigerian case study also exemplifies the role of external actors in facilitating, exacerbating and perpetuating conflict over resources. Consequently, Nigeria is not an isolated case on the African continent in particular and throughout the world as a whole. The presence of natural resources acts as a catalyst for either conflict or repression or both (Omeje, 2004:431).

\section{Conclusion: A new cold war for oil, the United States, China and Africa?}

In conclusion, there seem to be two scenarios, which could play out over the short term. The first is a more pessimistic view, which regards the actions of both Washington and Beijing as having the potential to exacerbate conflict in Africa as a catalyst to the competition over scarce resources, power and legitimacy. As resources become increasingly important, the competition over who controls access to and distribution of the resources will similarly increase. In the same respect, as 
resources become scarcer, global powers will utilise ever-changing methods with little regard to implications and effects in order to maintain access to strategic resources and to secure national interest and security. It is thus that we see the US actively involved in securing the safety of oil fields within the Niger Delta regardless of the political implications it might have for the impoverished people of Nigeria. Another example is China's policy of respecting national sovereignty over human rights abuses, which has resulted in the financing of despotic regimes across Africa.

The involvement of both the US and China in Africa has resulted in a pragmatic quest for the own strategic interests of the former. Although African countries have gained in respect of increasing trade levels and investment, external involvement has exacerbated the root causes of conflict in African countries. The competition over influence on the African continent has also highlighted the growing rift between the US and China. As such, policy-makers in Washington will no longer see Beijing's actions and decisions within Africa as being outside a broader strategic framework (Alden, 2005:159), whilst, on the other hand, China perceives the US to be threatened by its rising economic power and status within the developing world (Rethinaraj, 2003:386). The implications point towards a growing competition over influence on the African continent, a competition in which Africa's people will continue to be sidelined in the interest of securing access to strategic resources, markets and diplomatic support.

The second scenario is a more optimistic one. In this scenario, great powers will firstly recognise that given growing interdependence, they would need to cooperate with each other to ensure maximum exploitation of available energy resources. Secondly, countries like China and the US realise that the making of politically repressed, underdeveloped areas in Africa is not in their interest in the long term. As the case of the Niger Delta illustrates, local communities could offer resistance by cutting pipelines and kidnapping staff from multinational companies and in the process undermine energy resource security. This scenario envisages, therefore, the development of a win-win situation where competition between great powers are lessened, where consensus as opposed to coercion is strengthened and where all stakeholders, including local communities, become part of such a consensus. There are some indications to suggest that such a consensus is taking shape. At the July 2006 St. Petersburg Summit of the G-8 countries, a statement on global energy security principles was released, which committed the G-8 leaders to:

- $\quad$ strong global economic growth, effective market access, and investment in all stages of the energy supply chain; 
- open, transparent, efficient and competitive markets for energy products, supply, use, transmission and transit services as a key to global energy security;

- transparent, equitable, stable and effective legal and regulatory frameworks (thereby hopefully minimising corruption);

- enhanced dialogue on relevant stakeholders' perspectives on growing interdependence, security of supply and demand issues, diversification of supply and demand issues, energy sources, geographical and sectoral markets, transportation routes and means of transport;

- environmentally sound development and use of energy and development and transfer of clean energy technologies which help to tackle climate change;

- promotion of transparency and good governance in the energy sector to discourage corruption; and

- addressing the energy challenges for the poorest populations in developing countries.

(Statement on Global Energy Security Principles, 2006).

It is much too early to comment on the success of this second scenario since it is still in its early days of implementation. However, the fact that those great powers can acknowledge that their competition for energy makes local communities, host governments and themselves insecure, suggests that there is some room for optimism. It is also gratifying that there is a clear acknowledgement that the route to sustainable energy security is through consultation and the promotion of good governance, as well as by addressing the challenges of the poor and marginalised.

\section{References}

Alden, C. 2000. The United States and its New Paradigm for Africa. African Affairs. 99:355-371.

Alden, C. 2005. China in Africa. Survival. 47(3):147-164.

Barnes, S. 2005. Global Flows, Terror, Oil and Strategic Philanthropy. Review of African Political Economy. 104(5):235-252.

Biel, R. 2003. Imperialism and International Governance: The Case of US Policy Towards Africa. Review of African Political Economy. 95:77-88. 
Bromley, S. 2005. The United States and the Control of World Oil. Government and Opposition. 23:225-256.

Bush, R. 2004. An African Scramble. Review of African Political Economy. 101:383-384.

Giry, S. 2004. China's Africa Strategy: Out of Beijing. The New Republic. Nov. $15^{\text {th }}: 19-23$.

Hale, D. 2006. China's Economic Takeoff: Implications for Africa. Brenthurst Discussion Paper. 1/2006.

Ikelegbe, A. 2005. The Economy of Conflict in the Oil Rich Niger Delta Region of Nigeria. Nordic Journal of African Studies. 14(2):208-234.

Jaffe, A. and Lewis, S. 2002. Beijing’s Oil Diplomacy. Survival. 44(1):115-134.

Jenkins, R. and Edwards, C. 2004. How does China's Growth Affect Poverty Reduction in Asia, Africa and Latin America? Norwich: Overseas Development Group.

Keenan, J. 2004. Terror in the Sahara: the Implications of US Imperialism for North and West Africa. Review of African Political Economy. 101:475-496.

Kraxberger, B. 2005. The United States and Africa: Shifting GeoPolitics in an Age of Terror. Africa Today. 12(1):47-70.

Le Billon, H. 2004. The GeoPolitical Economy of "Resource Wars". The GeoPolitical Economy of Resource Wars. 91(8):1-28.

Lee, P.K. 2005. China’s Quest for Oil Security: Oil Wars in the Pipeline. The Pacific Review. 18(2):265-301.

McLaughlin, A. 2005. A Rising China Counters US Clout in Africa. Christian Science Monitor. 97(87):1-2. pp. 4-5.

Mills, G and Skidmore, N. 2004. Towards China Inc? Assessing the Implications for Africa. Johannesburg: SAIIA. 
Muekalia, D.J. 2004. Africa and China’s Strategic Partnership. African Security Review. 13(1):5-12.

Omeje, K. 2004. The State, Conflict and Evolving Politics in the Niger Delta. Review of African Political Economy. 101: 425-440.

Osaghae, E.E. 2004. Political Transition and Ethnic Conflict in Africa. Journal of Third World Studies. Spring:220-241.

Peters, S. 2004. Coercive Western Energy Security Strategies: Resource Wars as a New Threat to Security. The GeoPolitical Economy of Resource Wars. 91(8):187212.

Pocha, J. 2005. Rising China: The GeoPolitics of Oil. National Policy Quarterly. Winter:50-56.

Rethinaraj, T.S. 2003. China’s Energy and Regional Security Perspectives. Defense and Security Analysis. 19(4):377-388.

Statement on Global Energy Security Principles. Communique of the G-8. St Petersburg, Russia, 16 July 2006. [Online] http://www.eni-g8russia.ru/docs/11/html. [22 January 2007].

Taylor, I. 1997. The Two Chinas Compete in Africa. Contemporary Review. 271(1581):192-196.

Taylor, I. 1998. China’s Foreign Policy Towards Africa in the 1990s. The Journal of Modern African Studies. 36(3):443-460.

Tefft, S. 1996. Taiwan and China Butt Heads in Africa. Christian Science Monitor. 88(61):7.

Thayer, B. 2005. Confronting China: An Evaluation of Options for the United States. Comparative Strategy. 24:71-98.

Umbach, F. 2004. Global Energy Supply and Geopolitical Challenges. In: François Godement, Françoise Nicolas, and Taizo Yakushiji, eds. 2004. Asia and Europe Cooperating for Energy Security. Massachusetts: Brookings Institution. 137-168. 
Verrastro, F., Placke, J.A., Hegburg, A.S. 2004. Securing US Energy in a Changing World. Middle East Policy. XI(4): 1-25.

Volman, D. 2003. The Bush Administration and African Oil: The Security Implications of US Energy Policy. Review of African Political Economy. 98:573584.

Zalik, A. 2004. The Niger Delta: Petro Violence and Partnership Development. Review of African Political Economy. 101:401-424. 